\title{
Biosolids as planting fertilization of tree species of the Atlantic forest and concentration of nutrients in soil layers
}

\author{
Biosólidos como fertilización en plantación de especies de árboles nativos del bosque atlántico \\ y concentración de nutrientes en capas del suelo
}

\author{
Pedro Lima Filho a , Rodrigo Ferreira Gomes ${ }^{\text {a*, Juçara Garcia Ribeiro a }}$, \\ Alan Henrique Marques de Abreu ${ }^{b}$, Flávio Augusto Monteiro dos Santos ${ }^{\text {, }}$ Paulo Sérgio dos Santos Leles ${ }^{a}$ \\ *Corresponding author: a Federal Rural University of Rio de Janeiro, Forest Institute, Department of Forestry, \\ Seropédica - RJ, Brazil, tel.: 55-21-965023554, rodrigoferreiragomes1@hotmail.com \\ ${ }^{\mathrm{b}}$ Water and Sewerage Company of the State of Rio de Janeiro, Rio de Janeiro - RJ, Brazil, \\ alanhenriquem@gmail.com \\ ${ }^{\mathrm{c}}$ Basin Agency of the Paraíba Valley, Resende - RJ, Brazil, monteiro.flaviosantos@gmail.com
}

\begin{abstract}
SUMMARY
Sewage sludge biosolids, product from urban sewage treatment, are rich in organic matter and nutrients with potential use in forestry. This work aimed at evaluating the growth of Ceiba speciosa, Peltophorum dubium and Sapindus saponaria and the concentration of nutrients and heavy metals in different soil layers under the application of biosolids as planting fertilizer. Two sequential experiments were set up. First in a pot, to determine the best dose for the growth of C. speciosa, using 0.8, 1.6, 3.2 and 6.4 liters of biosolids per pit and the absolute witness. Six months after the planting of $C$. speciosa seedlings, it was concluded that the best dose provided was around 3.9 liters. The field experiment was carried out using the three tree species with witness treatment or application of 3.0 liters of biosolids per pit, at the time of planting. Growth evaluations occurred at 4 and 12 months after planting and it was observed that $C$. speciosa and P. dubium responded to the application of biosolids. At 12 months, nitrogen, phosphorus, potassium and heavy metals contents were evaluated in different layers of the soil. It was found that the pits that received biosolids presented significantly higher values for phosphorus (except 75-100 cm soil layer) and heavy metals. There was no leaching of nitrogen, phosphorus and potassium in the soil layers. Heavy metals contents were below the maximum values for levels in the soil profile stipulated by legislation.
\end{abstract}

Key words: sewage sludge, Ceiba speciosa, Peltophorum dubium and Sapindus saponaria.

\section{RESUMEN}

El biosólido de lodos de depuradora, producto del tratamiento de aguas residuales urbanas, es un material rico en materia orgánica y nutrientes con potencial uso en silvicultura. El objetivo fue evaluar el crecimiento de Ceiba speciosa, Peltophorum dubium y Sapindus saponaria y la concentración de nutrientes y metales pesados en diferentes capas del suelo con aplicación de biosólido como fertilizante al plantar. Se establecieron dos experimentos secuenciales. Primero, en maceta para determinar la mejor dosis para el crecimiento de $C$. speciosa $(0,8,1,6,3,2$ y 6,4 litros de biosólidos por taza) y el testigo absoluto. Seis meses después de plantar $C$. speciosa se concluyó que la mejor dosis fue de alrededor de 3,9 litros. Segundo, el experimento de campo utilizó las tres especies de árboles con tratamiento testigo o aplicación de 3.0 litros de biosólidos por hoyo, al momento de plantar. Después de 4 y 12 meses de plantar, C. speciosa y P. dubium respondieron a la aplicación de biosólidos. A los 12 meses fueron evaluados los contenidos de nitrógeno, fósforo, potasio y metales pesados en diferentes capas del suelo. Se encontró que las tazas que recibieron biosólidos tenían valores de fósforo significativamente mayores (excepto la capa de suelo de 75-100 cm) y metales pesados. No hubo lixiviación de nitrógeno, fósforo ni potasio en las capas del suelo. Los contenidos de metales pesados en el perfil del suelo estuvieron por debajo de los valores máximos estipulados por la legislación.

Palabras clave: lodos de depuradora, Ceiba speciosa, Peltophorum dubium, Sapindus saponaria.

\section{INTRODUCTION}

The Atlantic Forest biome corresponds to $15 \%$ of the Brazilian territory area and concentrates around $72 \%$ of the population (IBGE 2014), with the vast majority resi- ding in urban areas. According to data from INPE (2018), $12.4 \%$ of the forest cover remains, usually in the form of forest fragments, thus requiring reforestation actions with species that occur in this biome. Furthermore, in many rural properties in Brazil, there is a need for reforestation in 
areas of permanent preservation and constitution of legal reserve areas to adapt to the Federal Law 12.651/12.

The concentration of population in certain regions generates large amounts of waste, such as the production of sanitary sewage, which must be sent to sewage treatment stations. During this treatment, the solid part is decanted and the sewage sludge is obtained, which after due treatment, stabilization and meeting the microbiological and chemical criteria established by CONAMA Resolution 498/2020 (Brazil 2020) is called biosolids. The destination of a large part of the biosolids produced in the sewage treatment stations is still landfills, burdening sanitation companies and contributing to reduce the useful life of landfills.

In the metropolitan region of Rio de Janeiro, which is nestled in Mata Atlântica biome, one of the most populous in Brazil, according to information from engineers, the State Water and Sewer Company pays around U\$ 50.00 per ton (price taken in December 2019) for deposition of biosolids in landfills. Considering the chemical and physical characteristics and that the biosolids from sewage treatment stations in the metropolitan region of Rio de Janeiro meet the parameters of CONAMA Resolution 498/2020 and are rich in nutrients and organic matter (Abreu et al. 2017, Cabreira et al. 2017, Alonso et al. 2018, Sousa et al. 2019), its use as fertilizer for planting tree species can give a more sustainable destination to this material. In addition, Art. 20, $\$ 2^{\circ}$ and Art. 21, $\$ 3^{\circ}$ of CONAMA resolution 498/2020 mention that "there is no restriction for the application of biosolids in planted forests, soil recovery and degraded areas".

Normally, rural producers in Brazil use the best areas of the property for food production or animal husbandry, therefore forest restoration occurs in areas that are poor in nutrients and organic matter, and it is necessary, according to Gonçalves (1995), in many situations to fertilize planting. For forest restoration, there are some planting fertilization works with sewage sludge biosolids from tree species occurring in the Atlantic forest (Paiva et al. 2009, Silva and Pinto 2010, Lopes and Leles 2020, Silva et al. 2020) and the responses have been quite different, depending on the edaphic and climatic conditions where the stands are located and the differences in behavior of native tree species. Another characteristic of the biosolid is when applied to the soil, its substances have a high power of adsorption to the soil and thus, according to Campos et al. (2019), there is no leaching to deeper layers of soil, there is no risk of contamination of the water table. Further field studies on this topic are indicated, due to the large differences in soil and climatic conditions existing in Brazil.

In the formation of stands for the restoration of the Atlantic Forest, diversity of tree species is usually used trying to imitate what occurs in the forest. Among the species commonly used are Ceiba speciosa (A. St.-Hil.) Ravenna, Peltophorum dubium (Spreng.) Taub. and Sapindus saponaria $\mathrm{L}$. The first belongs to the Malvaceae family, is clas- sified as a pioneer stage and has a relatively rapid growth, in addition to being a species that has a wide geographical distribution in the Brazilian territory (Lorenzi 1992). Peltophorum dubium belongs to the Fabaceae family, a pioneering species, which is relatively fast-growing and deciduous. Its wood can be used for various purposes, its flowers, in addition to meliferous, have a great ornamental effect (Lorenzi 1992). Sapindus saponaria belongs to the Sapindaceae family, according to Lorenzi (1992), it is a species of the secondary successional stage, a characteristic broadleaved semideciduous forest and comparatively slower in growth than the other two species.

The hypothesis of this work is that the three tree species occurring in the Atlantic Forest will be responsive to biosolids as planting fertilizers and that it will not contaminate the soil, based on the "maximum permitted values of chemical substances" of Art. 10 of CONAMA Resolution 498/2020.

The objective is to evaluate the growth of Ceiba speciosa, Peltophorum dubium and Sapindus saponaria and the concentration of nutrients and heavy metals in the different layers of the soil under the application of the biosolid as planting fertilizer.

\section{METHODS}

The work was divided into two sequential stages: the first one was an experiment in pots to verify the response of Ceiba speciosa to biosolids doses. Based on this information and on the operational aspect of transport and application of biosolids, a field experiment was carried out with the absence and presence of biosolids as fertilization in a pit, in the operation of planting the seedlings of three tree species.

Stage 1 - Pots conditions. This stage was carried out in the municipality of Seropédica, State of Rio de Janeiro, from November to May, in pots with volumetric dimensions of 18 liters, with a smaller diameter of $25 \mathrm{~cm}$, larger diameter of $30 \mathrm{~cm}$ and a height of $28 \mathrm{~cm}$, simulating a planting pit. The climate of the region, according to Koppen's classification, is of Cwa type. The soil used came from the 0-40 $\mathrm{cm}$ layer of a slope, classified expeditiously (in the field) and based on results of chemical analyses by a professor in the field of genesis, soil physics, as dystrophic endoalic Yellow Latosol with clay texture, whose chemical analysis is shown in table 1 .

For the definition of biosolids doses, the application of $\mathrm{P}_{2} \mathrm{O}_{5}$ for planting fertilization in native species recommended by Gonçalves (1995) was considered, both in the chemical analysis of pot soil (table 1) and in the chemical analysis of biosolid (table 2). Based on this information, a standard dose of 3.2 liters of biosolids per pot was adopted. The other doses were $1 / 4$, half and twice the standard dose, that is, $0.8,1.6,3.2$ and 6.4 liters of biosolids per pot, in addition to absolute witness. The biosolid had an avera- 
Table 1. Chemical analyses of soils used for the growth of tree species in planting fertilization experiments.

Análisis químico de suelos utilizados para el crecimiento de especies arbóreas en experimentos de fertilización de plantaciones.

\begin{tabular}{|c|c|c|c|c|c|c|c|c|c|}
\hline Stage & $\mathrm{pH}$ & $\mathrm{P}$ & $\mathrm{K}^{+}$ & $\mathrm{Ca}^{2+}$ & $\mathrm{Mg}^{2+}$ & $\mathrm{Al}^{3+}$ & $\mathrm{H}+\mathrm{Al}$ & $\mathrm{SB}$ & CTC $(\mathrm{t})$ \\
\hline & $\mathrm{H}_{2} \mathrm{O}$ & \multicolumn{2}{|c|}{------ $\mathrm{mg} \cdot \mathrm{dm}^{-3}$-------- } & \multicolumn{6}{|c|}{ - } \\
\hline Pot & 5.1 & 1.0 & 27 & 0.4 & 0.2 & 0.9 & 4.5 & 1.7 & 1.9 \\
\hline Field & 5.7 & 3.3 & 115 & 1.3 & 0.5 & 0.0 & 3.3 & 2.1 & 2.4 \\
\hline
\end{tabular}

$\mathrm{pH}$ in water; phosphorus and potassium: Mehlich extractor 1; calcium, magnesium and aluminum: 1.0 nitrogen $\mathrm{KCl}$ extractor; hydrogen+aluminum: calcium acetate extractor $0.5 \mathrm{~N}-\mathrm{pH} 7.0 ; \mathrm{SB}=$ sum of exchangeable bases; CTC $(\mathrm{t})=$ effective cation exchange capacity.

Table 2. Total elements, organic carbon (CO) and biosolid $\mathrm{pH}$ used in the experiments, from the sewage treatment of Alegria, located in Rio de Janeiro City, Brazil.

Elementos totales, carbono orgánico (CO) y pH de biosólidos utilizados en los experimentos, del tratamiento de aguas residuales de Alegría, ubicada en la ciudad de Río de Janeiro.

\begin{tabular}{|c|c|c|c|c|}
\hline Nutrients & Amount & Heavy metals & Content $\left(\mathrm{mg} \mathrm{kg}^{-1}\right)$ & Maximum limit ( $\mathrm{mg} \mathrm{kg}^{-1}$ total solids)* \\
\hline Nitrogen $\left(\mathrm{g} \mathrm{kg}^{-1}\right)$ & 17.2 & Arsenic & 1.3 & 41 \\
\hline Phosphorus ( $\left.\mathrm{g} \mathrm{kg}^{-1}\right)$ & 7.5 & Barium & 462.2 & 1.300 \\
\hline Potassium $\left(\mathrm{g} \mathrm{kg}^{-1}\right)$ & 2.1 & Cadmium & 2.3 & 39 \\
\hline Calcium $\left(\mathrm{g} \mathrm{kg}^{-1}\right)$ & 17.2 & Lead & 191.9 & 300 \\
\hline Magnesium $\left(\mathrm{g} \mathrm{kg}^{-1}\right)$ & 3.0 & Copper & 354.0 & 1.500 \\
\hline Sulfur $\left(\mathrm{g} \mathrm{kg}^{-1}\right)$ & 8.5 & Chrome & 172.1 & 1.000 \\
\hline Organic carbon $(\%)$ & 17.4 & Mercury & 0.7 & 17 \\
\hline \multirow[t]{4}{*}{$\mathrm{pH}\left(\mathrm{H}_{2} \mathrm{O}\right)$} & 5.0 & Molybdenum & 1.1 & 50 \\
\hline & & Nickel & 53.2 & 420 \\
\hline & & Selenium & 1.2 & 36 \\
\hline & & Zinc & 1.103 & 2.800 \\
\hline
\end{tabular}

Nitrogen - Kjeldahl method; organic carbon - Walkley Method - Black and others determined in the acid extract (nitric acid with perchloric acid). * Maximum permitted levels of chemical substances in Class 1 biosolids to be used for soil use, according to Art. 20, $\$ 2^{\circ}$ of resolution CONAMA $498 / 2020$.

ge density of $0.65 \mathrm{~g} \mathrm{~cm}^{-3}$, corresponding approximately to $0.5,1.0,2.0$ and $4.0 \mathrm{~kg} \mathrm{pot}^{-1}$, respectively.

The biosolids used in both experiments come from the Alegria Sewage Treatment Station, located in the Caju neighborhood, city of Rio de Janeiro - RJ. The material was provided by the Rio de Janeiro State Water and Sewage Company (CEDAE). The treated sewage is derived from urban households and commercial areas. In this sewage treatment station, the primary treatment is carried out, which consists of the chemically assisted method (use of aluminum sulphate or ferric chloride as a sludge coagulant) and the secondary treatment is using the activated sludge system. The sludge from the secondary treatment is thickened and mixed with the sludge from the primary treatment to pass through a dewatering centrifuge. After this process, the material is taken to the thermal dryer, where it remains until it reaches low moisture content. Finally, it is deposited in a dry and ventilated place until complete composting. Chemical analyses of the biosolids are shown in table 2 .

The biosolids doses were mixed with the soil and afterwards, the pots were filled with the soil-biosolids mixture. For the absolute witness, the pots were filled only with soil. After filling, Ceiba speciosa seedlings were planted in tubes of $280 \mathrm{~cm}^{3}$, with a standard height of $50 \mathrm{~cm}$. The substrate used for the production of seedlings was composed by $90 \%$ commercial substrate and $10 \%$ clayey soil.

The experiment was installed in a completely randomized design, composed by five replications of a single plant. Due to temperature and precipitation condi- 
tions at the time of the experiment, when it did not rain, once a day the plants were irrigated with 1.5 liters of water. When necessary, spontaneous plants were removed to avoid competition interference.

Six months after planting the seedlings, height and crown diameter of plants were measured. Data were submitted to a regression analysis, in which the growth curves were constructed according to the control and the biosolids doses.

Stage 2 - Field. The study was conducted in a settlement formation area for forest restoration in the Municipality of Bom Jardim, State of Rio de Janeiro. According to data from 2012 to 2014 from the nearest meteorological station to the experiment spot, the average annual precipitation in this period was $1.378 \mathrm{~mm}$, with rainfall concentration from November to March and a dry period from June to September. The minimum annual average temperature was $16.0^{\circ} \mathrm{C}$ in July, and the maximum average was $28.0^{\circ} \mathrm{C}$ in February, with average annual temperature of $22.0^{\circ} \mathrm{C}$. The average altitude of the region is 530 meters.

The experiment was implemented in January (midrainy season) 2013 , in poorly managed pasture, dominated by weed species belonging to the genus Urochloa sp., located in the middle third of a slope. The soil in the experimental area was classified as Yellow Red Latosol with clay texture ( $46 \%$ clay, $16 \%$ silt and $38 \%$ sand), whose chemical analyses of the $0-30 \mathrm{~cm}$ layer are shown in table 1 . The experiment was intended to be carried out in the same area that was removed from the pot experiment (stage 1), though, at the time, the area had not been surrounded and the reforestation was not taking place.

Treatments consisted in the application of $3.0 \mathrm{~L}$ of biosolids per pit, whose chemical characteristics are shown in the table 2 , corresponding to approximately $2 \mathrm{~kg}$ mixed with the soil of the pit and absolute witness. This dose of biosolids was based on the results of the pot stage, the chemical analysis of the soil (table 1) and the execution of the operation to transport the biosolids to the middle third of the slope. For each species, each treatment was formed by twelve repetitions, of a plant, adopting a completely randomized design. The planting spacing was $2 \mathrm{~m} \times 2 \mathrm{~m}$.

The species used were Ceiba speciosa, Peltophorum dubium. and Sapindus saponaria. The seedlings were produced in plastic bags of $9.7 \times 20 \mathrm{~cm}$ (diameter x height), on a substrate composed by tanned bovine manure, clay subsoil and washed sand, in a volumetric ratio of $5: 4: 1$. At the time of planting, the seedlings were approximately 80,35 and $60 \mathrm{~cm}$ high for Ceiba speciosa, Peltophorum dubium and Sapindus saponaria, respectively.

To prepare the soil for planting, initially the pits were marked in a level direction, obeying the pre-defined spacing. Next morning and with wind speed below $10 \mathrm{~km} / \mathrm{h}$, a glyphosate-based herbicide was applied over a total area (dose of $4.0 \mathrm{~L} \mathrm{ha}^{-1}$ ), using a costal sprayer with capacity of 16 liters. After 20 days, the surrounding of the pits was crowned, approximately $60 \mathrm{~cm}$ in diameter. The pits were opened with the aid of a hoe, with the dimensions of $25 \mathrm{x}$ $25 \times 30 \mathrm{~cm}$ (length $\mathrm{x}$ width $\mathrm{x}$ depth). Subsequently, in half of the pits, 3.0 liters of biosolid were fertilized and the seedlings were planted.

The cultural treatments involved control of leaf-cutting ants (before, during and until the end of the experiment) and weed control, with crown and mowing in May and October 2013, and the application of glyphosate (dose of $2.5 \mathrm{~L} \mathrm{ha}^{-1}$ ) in November 2013, to minimize the effects of competition with other plants.

For growth evaluation, the variables shoot height and diameter at $5 \mathrm{~cm}$ from the soil surface (D5) were measured at 4 and 12 months after planting. In this last evaluation, the transverse (L1) and longitudinal (L2) widths of the tree planting line were also measured for the calculation of the crown area (Ci), considering them as an ellipse [1]:

$$
\left.C_{i=} \pi\left[\left(\mathrm{L}_{1}+\mathrm{L}_{2}\right) / 4\right)^{2}\right]
$$

Where: $C_{i}=$ crown area $\left(\mathrm{m}^{2}\right) ; L_{1}=$ transverse crown width (m); $L_{2}=$ longitudinal crown width (m).

Soon after measurements and analyses of height and D5 data, performed 12 months after planting, the four plants closest to the average height of Ceiba speciosa and Sapindus saponaria were chosen from the two treatments used, to analyze the concentration of nitrogen, phosphorus and potassium and also heavy metals (chromium, nickel, cadmium and lead) in the soil profile. The choice of these two species was aimed at covering the species with relatively fast growth (Ceiba speciosa) and the slowest (Sapindus saponaria), observed with height and diameter measurements. This analysis consisted of collecting soil samples, up to $10 \mathrm{~cm}$ away from the base of the plant stem, in layers of depth $0-25,25-50,50-75$ and $75-100 \mathrm{~cm}$, with a probe. The soil samples from the different layers were dried in air and subjected to chemical analyses at the Laboratory of Chemical Analyses of Soil, Vegetable Tissue and Fertilizers of the Federal University of Viçosa, to obtain the concentration of nitrogen, phosphorus, potassium and heavy metals. These data, together with the growth data, in both seasons were subjected to the homoscedasticity tests of variance and normality of the residues, verifying that there is no need for data transformation. Accordingly, they were submitted to an analysis of variance. Subsequently, for the levels of nutrients and heavy metals between soil layers, with significant differences being verified by the $\mathrm{F}$ test, these were subjected to the Tukey test $(P \geq 0.95)$.

\section{RESULTS}

In the pot experiment evaluation, Ceiba speciosa plants showed responses with quadratic equations of height and crown diameter (figure 1) in relation to the treatments, showing that the maximum growth point, for these condi- 
tions, is between 3.9 and $4.2 \mathrm{~L}$ per pot of biosolids. With this information and in accordance with the logistics of transportation and distribution of biosolids in the pits, it was decided to use the fertilization of 3.0 liters of biosolids per pit, for the field experiment. Another important observation of figure 1 is that the coefficient of determination $\left(\mathrm{R}^{2}\right)$ was relatively low, mainly in height, indicating a high dispersion of the data, even in pots conditions and the care taken.

On field conditions, it can be seen from table 3 that the plants of Peltophorum dubium fertilized with 3.0 liters of biosolids per pit showed a significantly higher growth than that shown by those unfertilized. For Ceiba speciosa the difference was not significant only for height, at four months after planting and for Sapindus saponaria, three of the five evaluations did not show significant differences.

In evaluating the concentrations of nitrogen, phosphorus and potassium and heavy metals in the pit region at 12 months after planting, it was found that, for all four layers, there were no significant differences in the concentration of nutrients and heavy metals among samples removed in the pits of Ceiba speciosa and Sapindus saponaria $(P \geq 0.95)$. Thus, the data presented in tables 4 and 5 refer to the average levels, based on data from the two species.

Regardless of the layer of the soil profile evaluated, it appears that there were no significant differences in the
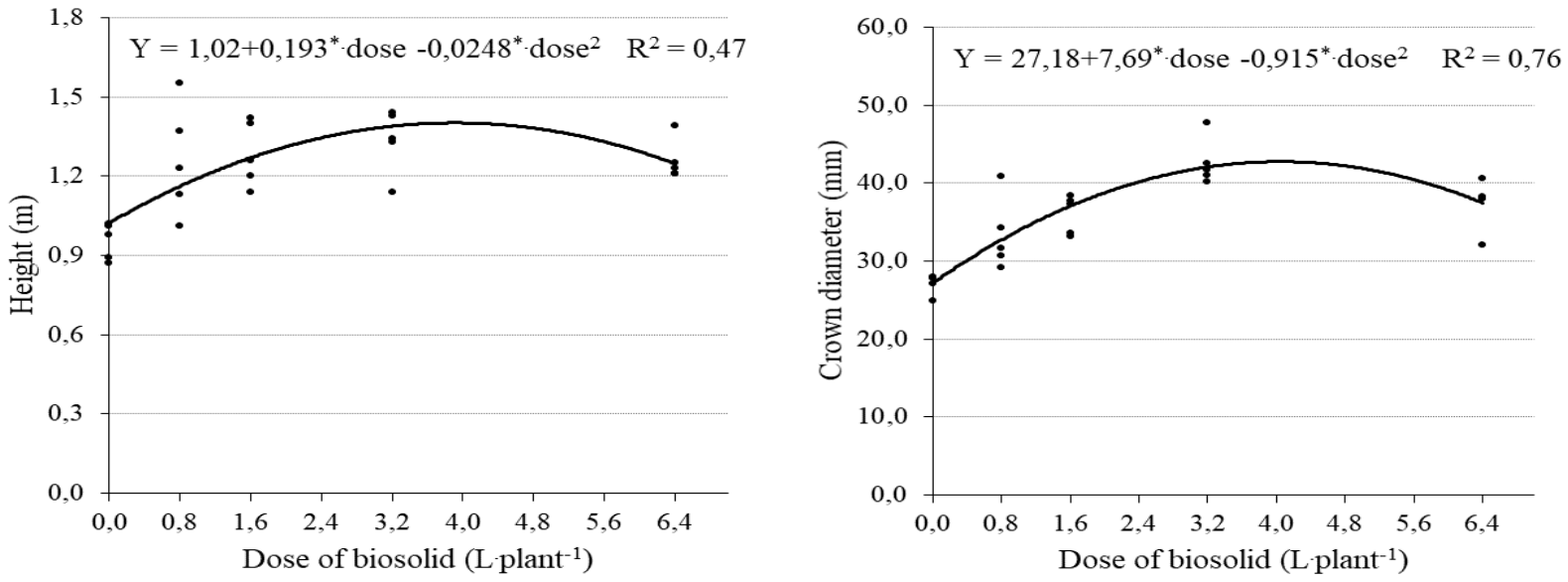

Figure 1. Height of the aerial part and crown diameter of the Ceiba speciosa on the basis of biosolids per plant grown in pots, six months after planting, in pots. * significant at $1 \%$, using the $\mathrm{t}$ test.

Altura de la parte aérea y diámetro de copa de Ceiba speciosa según biosólidos por planta cultivada en maceta, seis meses después de la plantación, en maceta. * significativo al $1 \%$, utilizando la prueba t.

Table 3. Average values (and standard deviation) of three tree species at 4 and 12 months after planting, submitted to fertilization with 3 liters of biosolids or without fertilization, for the formation of stands for forest restoration, in the state of Rio de Janeiro, Brazil.

Valores promedio (y desviación estándar) de tres especies arbóreas a los 4 y 12 meses después de la plantación, sometidas a fertilización con 3 litros de biosólidos o sin fertilización, para la formación de rodales para restauración forestal, en el estado de Río de Janeiro, Brasil.

\begin{tabular}{|c|c|c|c|c|c|c|}
\hline \multirow[t]{2}{*}{ Specie } & \multirow[t]{2}{*}{ Biosolids } & \multicolumn{2}{|c|}{--- 4 months after planting --- } & \multicolumn{3}{|c|}{---------------12 months after planting -------- } \\
\hline & & Height (m) & $\mathrm{D} 5^{1}(\mathrm{~cm})$ & Height (m) & $\mathrm{D}^{1}(\mathrm{~cm})$ & Crown diameter $\left(\mathrm{m}^{2}\right)$ \\
\hline \multirow{2}{*}{ Peltophorumdubium } & $3.0 \mathrm{~L} \mathrm{pit}^{-1}$ & $0.75 *(0.15)$ & $1.83 *(0.29)$ & $1.94 *(0.42)$ & $4.54 *(1.10)$ & $2.31 *(1.14)$ \\
\hline & Absent & $0.41(0.06)$ & $0.99(0.12)$ & $1.48(0.37)$ & $3.42(0.70)$ & $0.94(0.53)$ \\
\hline \multirow{2}{*}{ Ceiba speciosa } & $3.0 \mathrm{~L} \mathrm{pit}^{-1}$ & $1.09^{\text {n.s }}(0.13)$ & $2.75 *(0.58)$ & $2.43 *(0.52)$ & $8.23 *(2.01)$ & $3.88 *(2.66)$ \\
\hline & Absent & $1.01(0.08)$ & $1.56(0.21)$ & $1.78(0.33)$ & $5.84(1.50)$ & $0.97(0.84)$ \\
\hline \multirow{2}{*}{ Sapindus saponaria } & $3.0 \mathrm{~L} \mathrm{pit}^{-1}$ & $0.74^{\text {n.s }}(0.10)$ & $1.09 *(0.21)$ & $1.16 *(0.24)$ & $2.59^{\text {n.s }}(0.70)$ & $0.18^{\text {n.s }}(0.10)$ \\
\hline & Absent & $0.64(0.10)$ & $0.76(0.20)$ & $0.76(0.16)$ & $1.94(0.61)$ & $0.13(0.07)$ \\
\hline
\end{tabular}

${ }^{1}$ Diameter $5 \mathrm{~cm}$ from the soil surface. For the same species, age e growth profile, ${ }^{*}$ indicates significantly higher mean by the $\mathrm{F}$ test $(P \geq 0.95)$ and ${ }^{\text {n.s }}$ averages do not present significant differences by the $\mathrm{F}$ test $(P \geq 0.95)$. 
levels of nitrogen and potassium of the soil of the pits that received biosolids and levels presented by those that did not receive (table 4). For phosphorus, significantly higher values were found, on average, in the pits that received 3.0 liters of biosolids, except for the 75 to $100 \mathrm{~cm}$ layer.

The average values of the concentration of nitrogen, phosphorus and potassium in the four evaluated layers of the soil presented in table 4 indicate that there was no leaching of nutrients in the layer of this soil classified as clayey, when 3 liters per biosolids pit were applied.

It can be seen from table 5 that the application of 3.0 liters of biosolids per pit provided significantly higher nic- kel, cadmium and lead contents in the pits that received biosolids, except for the last element in the 75 to $100 \mathrm{~cm}$ layer. No chromium content was found or it remained below Mehlich -1 method determination limit.

Even with the application of biosolids, the levels of the three heavy metals were much lower, in all layers, than the limits stipulated by Resolution $n^{\circ} .498 / 2020$ of the National Environment Council - CONAMA for the accumulation of heavy metals in the soil by the application of sewage sludge biosolids (Brasil 2020), corresponding respectively to average values of $9.4,1.0$ and $1.1 \%$ of this maximum value.

Table 4. Soil nutrient content after 12 months of 3 liters of biosolids application in the pit during planting of the seedlings and unfertilized treatment in four layers of soil in the area of settlement formation for forest restoration, state of Rio de Janeiro, Brazil.

Contenido de nutrientes del suelo después de 12 meses de aplicación de 3 litros de biosólidos en la taza durante la siembra de las plántulas y el tratamiento sin fertilizar en cuatro capas de suelo en el área de formación de asentamientos para restauración forestal, estado de Río de Janeiro, Brasil.

\begin{tabular}{ccccccc}
\hline Layer of soil & \multicolumn{2}{c}{---- Nitrogen $\left(\mathrm{g} \mathrm{kg}^{-1}\right)$} & \multicolumn{2}{c}{--- Phosphorus $\left(\mathrm{mg} \mathrm{dm}^{-3}\right)$--- } & \multicolumn{2}{c}{--- Potassium $\left(\mathrm{mg} \cdot \mathrm{dm}^{-3}\right)$--- } \\
\hline$(\mathrm{m})$ & $3.0 \mathrm{~L} \mathrm{pit}^{-1}$ & Absent & $3.0 \mathrm{~L} \mathrm{pit}^{-1}$ & Absent & $3.0 \mathrm{~L} \mathrm{pit}^{-1}$ & Absent \\
\hline $0.00-0.25$ & $1.8^{\text {n.s a }}$ & 1.7 & $29.8^{*} \mathrm{a}$ & 2.8 & $64.0 \mathrm{a}$ & $91.5^{\text {n.s }}$ \\
$0.25-0.50$ & $1.8^{\text {n.s }} \mathrm{a}$ & 1.7 & $7.3^{*} \mathrm{~b}$ & 2.1 & $54.1 \mathrm{a}$ & $78.0^{\text {n.s }}$ \\
$0.50-0.75$ & $1.6^{\text {n.s }} \mathrm{a}$ & 1.6 & $4.2^{*} \mathrm{~b}$ & 2.1 & $58.5 \mathrm{a}$ & $63.5^{\text {n.s }}$ \\
$0.75-1.00$ & $1.5^{\text {n.s }} \mathrm{a}$ & 2.1 & $3.4^{\text {n.s }} \mathrm{b}$ & 4.4 & $57.6 \mathrm{a}$ & $54.9^{\text {n.s }}$ \\
\hline
\end{tabular}

Nitrogen $=$ total nitrogen: sulfuric digestion-Kjeldhal distillation; phosphorus and potassium: Mehlich -1 extractor. For each nutrient and layer of soil, * indicates significantly higher mean by the $\mathrm{F}$ test $(P \geq 0.95)$ between the two treatments and ${ }^{\text {n.s }}$ averages do not show significant differences by the $\mathrm{F}$ test $(P \geq 0.95)$ between the two treatments. For the treatment with biosolids, average of the column followed by the same letter does not statistically differ by Tukey's test $(P \geq 0.95)$.

Table 5. Heavy metals in the soil $\left(\mathrm{mg} \mathrm{dm}^{-3}\right)$, after 12 months of application 3 liters of biosolids in the pit before planting and unfertilized treatment, in an area of settlement formation for forest restoration, state of Rio de Janeiro, Brazil.

Metales pesados en el suelo $\left(\mathrm{mg} \mathrm{dm}^{-3}\right)$, después de 12 meses de aplicación 3 litros de biosólidos en la taza antes de la siembra y tratamiento no fertilizado, en un área de formación de asentamientos para restauración forestal, estado de Río de Janeiro, Brasil.

\begin{tabular}{|c|c|c|c|c|c|c|}
\hline \multirow{2}{*}{$\begin{array}{l}\text { Layer of soil } \\
\qquad \text { (m) }\end{array}$} & \multicolumn{2}{|c|}{ Nickel $^{1}$} & \multicolumn{2}{|c|}{ Cadmium $^{1}$} & \multicolumn{2}{|c|}{ Lead $^{1}$} \\
\hline & Absent & $3.0 \mathrm{~L} \mathrm{pit}^{-1}$ & Absent & $3.0 \mathrm{~L} \mathrm{pit}^{-1}$ & Absent & $3.0 \mathrm{~L} \mathrm{pit}^{-1}$ \\
\hline $0.00-0.25$ & 0.09 & $0.30 * \mathrm{a}$ & 0.05 & $0.15 * a$ & 0.04 & $0.27 * \mathrm{a}$ \\
\hline $0.25-0.50$ & 0.09 & $0.26 * \mathrm{a}$ & 0.08 & $0.14 * \mathrm{a}$ & 0.02 & $0.10 * b$ \\
\hline $0.50-0.75$ & 0.10 & $0.21 * \mathrm{a}$ & 0.07 & $0.14 * \mathrm{a}$ & 0.01 & $0.06 * b$ \\
\hline $0.75-1.00$ & 0.08 & $0.13 * b$ & 0.08 & $0.10^{\text {n.s }} \mathrm{a}$ & 0.01 & $0.01^{\mathrm{n} . \mathrm{s}} \mathrm{bc}$ \\
\hline${ }^{2} \mathrm{CONAN}$ & $8 / 2020$ & 29.6 & & 1.6 & & 16.4 \\
\hline
\end{tabular}

${ }^{1}$ Extractor Mehlich -1. For each element, * indicates significantly higher mean by the $\mathrm{F}$ test $(P \geq 0.95)$ between the two treatments and ${ }^{\mathrm{n} . \mathrm{s}}$ averages do not show significant differences by the $\mathrm{F}$ test $(P \geq 0.95)$ between the two treatments. For the treatment with biosolids average of the column followed by the same letter does not statistically differ by Tukey's test $(P \geq 0.95)$. ${ }^{2}$ Maximum limit stipulated pela Resolução CONAMA n ${ }^{\circ} 498 / 2020$ for nickel, cadmium and lead contents in the soil by the application of sewage sludge biosolids. 


\section{DISCUSSION}

Positive responses for the application of biosolids in pots and field conditions probably occurred because the material had a relatively high content of nutrients and organic matter (table 2), as also reported by Abreu et al. $(2017,2019)$ and Sousa et al. (2019). Another factor is the improvement of physical conditions in the pit, as reported by Guerrini et al. (2017) and Balduino et al. (2020), the organic material of the biosolid acts as a soil conditioner, having a direct influence on the results presented by the plants, as it improves the chemical quality (Caldeira Junior et al. 2009) and the physical attributes, acting on the structure and state of aggregation particles, decreasing density and increasing aeration and moisture retention in the soil (Nobrega et al. 2007). In addition, tree species in the Atlantic forest live in environments relatively rich in organic matter and normally respond to fertilization with organic materials.

In pots conditions, the decline in growth curves in relation to the higher doses can be attributed to the fact that the biosolids excessively increase the amount of salts in the substrate, which can cause tissue necrosis, especially in roots, interfering in the growth of the plant (Arthur et al. 2007). Similar results were found by Maia (1999), in a study with Pinus taeda L., in which the biomass of the aerial part and roots showed quadratic effects regarding the increased use of sewage sludge biosolids. The feature of non-proportional gains is probably due to the biosolids, increasing the amount of nutrients in the soil in such a way that Ceiba speciosa, being a specie with no degree of improvement, is unable to assimilate nutrients with the same speed, which may cause loss of nutrients by leaching processes (Fernandes and Souza 2006, Novais et al. 2007). Silva et al. (2008) mention that when the doses of biosolids rise too high, the loss of productivity can be attributed, among other factors, to the possible limitation caused by the scarcest nutrients in the material, such as potassium.

Considering that the largest sewage treatment plants are in large urban centers, where a larger volume where most biosolids are produced (Abreu et al. 2017), it is important to analyze transport costs when choosing doses, as Ceiba speciosa plants did not respond linearly with increasing doses. Another factor is labor for the distribution of biosolids in the planting pits, which depends on the distance from where the biosolids lot is located in the field and the pits, in addition to the topography of the land.

In the field, responses significantly higher than those presented to the dose of 3.0 liters of biosolids per pit, in relation to the witnesses of the plants of Peltophorum dubium and Ceiba speciosa, probably occurred because these species are of pioneer successional stage (Lorenzi 1992) and because they present higher growth speed than that presented by Sapindus saponaria and, thus, responding more to fertilization. Responses differentiated by tree species in relation to the application of sewage sludge bioso- lids in the planting pit are also reported by other studies. Paiva et al. (2009) observed that Schinus terebinthifolia Raddi, Cytarexyllum myrianthum Cham. and Bauhinia forficata Link, which are considered pioneer species (Carvalho 2003) obtained a response to the application of $80 \mathrm{~g}$ biosolids in 4-liter pots better than that obtained by Myroxylon peruiferum L. $\mathrm{f}$., a species considered to be the final stage of succession (Lorenzi 1992).

Silva et al. (2020) concluded that Schinus terebinthifolia Raddi, Peltophorum dubium, Lafoensia glyptocarpa Koehne, Inga laurina (Sw.) Willd. and Senna multijuga (Rich.) benefited from the dose of $4 \mathrm{~L}$ biosolid per hole in a sandy texture planosol, while Genipa americana (Vell.) Brenan and Enterolobium contortisiliquum (Vell.) Morong did not respond to the application of biosolids. Lopes and Leles (2020) observed that in soil of the same classification as the field stage of this work, and relatively poorer in nutrients, the species Guarea guidonia L. Sleumer and Cordia superba Cham. responded to the application of 4.5 biosolids per pit, nonetheless, Inga laurina plants showed no significant differences in the pits that did not receive biosolids 18 months after the application and planting of the seedlings. The result of this work and those of the three other cited works indicate that the responses to the application of sewage sludge biosolids as planting fertilizers vary depending on the tree species and soil conditions. In addition, they show that the application of biosolids as planting fertilizer does not harm the growth of tree species.

Significantly higher means of nitrogen values were expected in the pits that received biosolids 12 months ago, as table 2 shows that this material is relatively rich in nitrogen. One possible explanation for the absence of differences is that, according to Souza and Fernandes (2006), the nitrogen is part of the leaf structures, having a direct influence on the crown area of the plants, being the element that most limits the growth of the plants. Thus, as the application of biosolids promoted more important growth of tree species and, as a consequence, there may have been higher absorption of nitrogen from the soil, no significant differences in the nitrogen content between the soils influenced by the pits of these two treatments may have occurred. Values of phosphorus content in the significantly higher pit, 12 months after application of biosolids in the pit, probably occurred due to the low content of this element in the soil (table 1). Based on data from table 2, the application of about $15 \mathrm{~g}$ of phosphorus, which corresponds to $34.4 \mathrm{~g}$ of $\mathrm{P}_{2} \mathrm{O}_{5}$ per pit, within the standards of 80 kg of $\mathrm{P}_{2} \mathrm{O}_{5}$ ha $^{-1}$, recommended by Gonçalves (1995), considering the $2 \times 2 \mathrm{~m}$ planting spacing used, corresponds to $32 \mathrm{~g}$ of $\mathrm{P}_{2} \mathrm{O}_{5}$ per pit.

Another factor is that the phosphorus present in organic materials, according to Novais et al. (2007) is usually in a complex form and is poorly soluble. In this way, they are gradually made available to the plants (Abreu et al. 2019), thus presenting significantly higher values in the pits where 3.0 liters of biosolids were applied 12 months 
ago. Absence of potassium $\left(\mathrm{K}^{+}\right)$response in the soil to the application of biosolids is due to the low content of this element in the biosolids (table 2). As the material dewatering phase occurs during its treatment, a step that takes some nutrients with water (Abreu et al. 2019), especially potassium, since it is an exchangeable base with oxidation number +1 , which makes a simple connection with oxyhydroxides and clays, while the exchangeable bases $+2\left(\mathrm{Ca}^{2+}\right.$ and $\mathrm{Mg}^{2+}$ ) create double bond.

Absence of significant differences in nitrogen, phosphorus (except for a $0-25 \mathrm{~cm}$ layer) and potassium indicates that there was no leaching of these nutrients until the depth of 1.0 meter of the soil surface in the pit 12 months after the application of 3.0 liters of biosolid. A significantly higher phosphorus value in the $0-25 \mathrm{~cm}$ layer is probably due to the low mobility of this element in the soil (Novais et al. 2007), mainly clayey, as in this work, and thus the phosphorus present in the biosolid was accumulated in the region of the pit, which provided values significantly higher than those of the contents in the most superficial layer.

Significantly higher differences in nickel, cadmium and lead in the soils that received 3.0 liters of biosolids in relation to the witness, occurred due to the presence of these elements in the biosolids (table 2), which are below the maximum limits stipulated by Art. 10 of CONAMA Resolution 498/2020. Data also indicate that there was no leaching of these elements in the 75 to $100 \mathrm{~cm}$ layer and that the values found in all layers are very low, corresponding to less than $10 \%$ of the maximum limits of CONAMA Resolution 498/2020 (Brasil 2020). Campos et al. (2019) studied the leaching from the application of 8 liters of sewage sludge biosolids in the layer of $0-25 \mathrm{~cm}$ of soil in columns of $20 \mathrm{~cm}$ in diameter, filled with clayey Latosols or sandy Planossols. They found in the samples of all collections, that in the leaching from both soils, the levels of nitrates, phosphates and heavy metals were below the limit stipulated by the CONAMA Resolution 498/2020 (Brasil 2020), showing that there is practically no possibility of soil layer contamination by the application of this dose of biosolids, even in sandy soils. Listing the dose used by Campos et al. (2019), with the $2 \times 2$ spacing used in this work, it corresponds to the application of $20 \mathrm{~m}^{3} \mathrm{ha}^{-1}$ and considering the density of $0.65 \mathrm{~g} \mathrm{~cm}^{-3}$ of the biosolids of this study, at $13 \mathrm{Mg} \mathrm{ha}^{-1}$.

Among the three heavy metals presented, the significant difference between lead content in the $0-25 \mathrm{~cm}$ layer and lower 75-100 cm layer should be highlighted. According to Maciel et al. (2012), heavy metals added by biosolids applications tend to remain in the area where the residue is incorporated into the soil (where the planting pit is covered) as a result of the interaction with oxides, clay minerals and organic matter, which will favor its use in forest restoration, since the number of interventions are smaller and less frequent than in agricultural crops. Normally, according to Silva et al. (2006) the inorganic constituents of the biosolids adsorb heavy metals, with no increase in availability expected over time and the tendency is to decrease the levels of metals in the soil, as the process of metal occlusion on the surfaces of the precipitates, which favors the application of biosolids in forest restoration.

\section{CONCLUSIONS}

For the conditions under which the field experiment was carried out, Ceiba speciosa and Peltophorum dubium plants showed higher growth with the application of 3 liters of biosolids per pit. Sapindus saponaria practically did not respond to the application of biosolids.

The pits fertilized with biosolids showed only significantly higher levels of phosphorus than those presented by unfertilized ones 12 months after application and planting of seedlings. Data indicate that there was no leaching of nitrogen, phosphorus and potassium in the soil layers.

Twelve months after the application of biosolids and planting of tree species seedlings, nickel, cadmium and lead contents in the soil were significantly higher in the fertilized pits, nonetheless, corresponding respectively to mean values of $9.4,1.0$ and $1.1 \%$ of the maximum soil limit stipulated by CONAMA Resolution 498/2020. Chromium contents were below those determined by the analytical method.

\section{ACKNOWLEDGEMENTS}

We thank PCH Santa Rosa for providing the place, support and labor for the accomplishment of the work.

\section{REFERENCES}

Abreu AHM, JM Alonso, LA Melo, PSS Leles, GR Santos. 2019. Caracterização de biossólido e potencial de uso na produção de mudas de Schinus terebinthifolia Raddi. Engenharia Sanitária e Ambiental 24(3): 591-599.

Abreu AHM, PSS Leles, JM Alonso, ELS Abel, RR Oliveira. 2017. Characterization of sewage sludge generated in Rio de Janeiro, Brazil, and perspectives for agricultural recycling, Semina: Ciências Agrárias 38(4): 2433-2448. DOI: http:// dx.doi.org/10.5433/1679-0359.2017v38n4Supl1p2433

Alonso JM, AHM Abreu, LA Melo, PSS Leles, GV Cabreira. 2018. Biosolids as substrate for the production of Ceiba speciosa seedlings. Cerne 24(4): 420-429. DOI: https://doi. org $/ 10.1590 / 01047760201824042568$

Arthur AG, MCP Cruz, ME Ferreira, VCM Barretto, R Yagi. 2007. Esterco bovino e calagem para formação de mudas de guanandi. Pesquisa Agropecuária Brasileira 42(6): 843-850.

Balduino APC, RS Corrêa, CBR Munhoz, JEQ Faria Júnior, JBA Bringel Junior, LS Barros. 2020. Manipulação de filtros ecológicos para aumentar a cobertura vegetal nativa em jazida tratada com lodo de esgoto no Bioma Cerrado. Ciência Florestal 30(2): 436-450. DOI:10.5902/1980509836476

Brasil. Resolução CONAMA no 498/2020. 2020. Define critérios e procedimentos para produção e aplicação de biossólido em solos. Diário Oficial da República Federativa do Brasil, Brasília, n. 161, p. 265-273. Available in https://www. 
in.gov.br/en/web/dou/-/resolucao-n-498-de-19-de-agostode-2020-273467970.

Cabreira GV, PSS Leles, JM Alonso, AHM Abreu, NF Lopes, GR Santos. 2017. Biossólido como componente de substrato para produção de mudas florestais. Floresta 47(2): 165-176. DOI: http://dx.doi.org/10.5380/rf.v47i2.44291

Caldeira Junior CF, Souza RA, Santos AM, Sampaio RA, Martins ER. 2009. Características químicas do solo e crescimento de Astronium fraxinifolium Schott em área degradada adubada com lodo de esgoto e silicato de cálcio. Revista Ceres 56(1): 213-218.

Campos T, G Chaer, PS Leles, M Silva, F Santos. 2019. Leaching of heavy metals in soils conditioned with biosolids from sewage sludge. Floresta e Ambiente 26: 1-10. DOI: 10.1590/2179-8087.039918

Fernandes MS, SR Souza. 2006. Absorção de nutrientes. In Fernandes MS ed. Nutrição mineral de plantas. Viçosa, Brasil. Sociedade Brasileira de Ciência do Solo. p. 115 - 152.

Gonçalves JLM. 1995. Recomendações de adubação para Eucalyptus, Pinus e espécies típicas da Mata Atlântica. Documentos Florestais 15: 1-23.

Guerrini IA, CGG Croce, OC Bueno, CPRP Jacon, TAR Nogueira, DM Fernandes. 2017. Composted sewage sludge and steel mill slag as potential amendments for urban soils involved in afforestation programs. Forestry and Urban Greening 22: 93-104. DOI: https://doi.org/10.1016/j. ufug.2017.01.015

IBGE (Instituto Brasileiro de Geografia e Estatistica, BR). 2014. Estimativas da população residente nos municípios brasileiros com data de referência em $1^{\circ}$ de julho de 2014. Consulted at 14 sep. 2020. Available in http://www.ibge. gov.br/home/estatistica/populacao/estimativa2014/estimativa dou.shtm

INPE (Instituto Nacional de Pesquisas Espaciais, BR). 2018. Atlas dos Remanescentes Florestais da Mata Atlântica - Período 2016-2017. São Paulo, Brasil. Fundação SOS Mata Atlântica. 63 p.

Lopes LN, PSS Leles. 2020. Biossólido de lodo de esgoto e fertilizantes químicos como adubação de plantio para espécies arbóreas: crescimento inicial e seus efeitos no solo. Revista Ineana (8): 28-43.

Lorenzi H. 1992. Árvores brasileiras: manual de identificação e cultivo de plantas arbóreas nativas do Brasil. Nova Odessa, Brasil. Plantarum. 352 p.

Maciel CAC, OA Camargo, SR Vieira, MK Chiba. 2012. Distribuição espacial de cobre, zinco e níquel em um Latossolo após quinze anos da aplicação de lodo de esgoto. Bragantia 71(4): 528-537. DOI: $10.1590 / \mathrm{S} 0006-$ 87052013005000008.

Nobrega RSA, RCV Boas, JCA Nobrega, AM Paula, FMS Moreira. 2007. Utilização de biossólido no crescimento inicial de mudas de aroeira (Schinus terebynthifolius Raddi). Revista Árvore 31(2): 239-246. DOI: 10.1590/S010067622007000200006 .

Novais RF, TJ Smyth, FN Nunes. 2007. Fósforo. In Novais RF, VVH Alvarez, NF Barros, RLF Fontes, RB Canturutti, JCL Neves eds. Fertilidade do solo. 2nd ed. Viçosa, Brasil. Sociedade Brasileira de Ciência do Solo. p. 471-550.

Paiva AV, F Poggiani, JLM Gonçalves, AV Ferraz. 2009. Crescimento de mudas de espécies arbóreas nativas, adubadas com diferentes doses de lodo de esgoto seco e com fertilização mineral. Scientia Forestalis 37(84): 499-511.

Silva BVN, LVA Pinto. 2010. Potencial do uso do lodo de esgoto como adubo orgânico em cobertura de espécies florestais nativas plantadas em área degradada por pastagem. Agrogeoambiental Review 2(1): 50-56. DOI: $10.18406 / 2316-$ $1817 \mathrm{v} 2 \mathrm{n} 12010251$.

Silva VB, AP Silva, BO Dias, JL Araújo, D Santos, RP Franco. 2014. Decomposition and release of N, P, and K of bovine manure and poultry litter isolated or mixed. Revista Brasileira de Ciência do Solo 38(5): 1537-1546.00. DOI: 10.1590/S0100-06832014000500019.

Silva MV, GM Chaer, PSS Leles, AS Resende AS, EV Silva, TO Campos. 2020. Use of biossolid in plantation of atlantic forest species. Scientia Forestalis 48(126): e2728. DOI: https://doi.org/10.18671/scifor.v48n126.16

Sousa TJS, JM Alonso, PSS Leles, ELS Abel, JG Ribeiro, JES Santana. 2019. Mudas de Luehea divaricata produzidas com biossólido de duas estações de tratamento de esgoto. Advances in Forestry Science 6: 595-601. DOI: 10.34062/ afs.v6i2.6992

Souza SR, MS Fernandes. 2006. Nitrogênio. In Fernandes MS ed. Nutrição mineral de plantas. Viçosa, Brasil. Sociedade Brasileira de Ciência do Solo. p. 215 - 252.

Recibido: $26 / 09 / 20$

Aceptado: 22/10/20 
